\title{
ПОЛИТоЛОГИЯ
}

\author{
K. А. Маркелов [K. A. Markelov]
}

\section{КОНЦЕПТ «БОЛЬШОГО КАСПИЯ» В КОНТЕКСТЕ ГЕОПОЛИТИЧЕСКОГО ИЗМЕРЕНИЯ}

\section{THE CONCEPT OF THE «GREAT CASPIAN» IN THE GEOPOLITICAL CONTEXT}

Астраханский государственный университет, г. Астрахань, Россия, E-mail: asu@asu.edu.ru/ Astrakhan stateUniversity, Astrakhan, Russia, E-mail: asu@asu.edu.ru

\begin{abstract}
Аниотация. Каспийская проблематика рассматривается в различных аспектах многочисленными отечественньми и зарубежсньми исследователями. Особое значение регион приобретает в связи с подписанием Конвениии о правовом статусе Каспийского моря (от 12.08.2018 г.), которая сформировала новые геополитические и геоэкономические реалии и новьий вектор интеграционного развития на евразийском континенте. Все больиее внимание уделяется тематике пространственного развития Больиого Каспия в системе координат «Восток-Запад» и «Север-ІОг». Политика СІІА на Ближнем Востоке, включающуал сапкиионное давление на Ираи, паправлена па дестабилизацио политико-экономической ситуаци в регионе, также предусматривает сдерживание поступательного развития крупнейиих азиатских экономик мupa.

В настоящей работе рассмотрены некоторье концептуальные подходы к формированию концепта и многомерной модели Больиого Каспия, как геополитического чентра региональных и глобальных интересов, динамичн меняюиего простраиственное сопряжение разновекторных сил международного влияния на основе институциональньх преобразований. Рас-

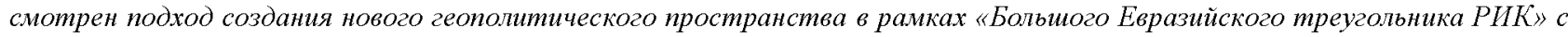
основанием треугольника "Больиого Каспия", стягивающего на себя ведущих игроков мировой политики и опоясывающегося Евразийский континент важнейиими транспортньии марирутами. Формирование «многомерньх пространств»треугольников, как наиболее устойчивых политико-экономических и физико-географических международных конструкииі (образований), представлятт собой пространственные реалии Больиого Каспия, как нового геополитического излерения мezapezuона.
\end{abstract}

Ключевые слова: геополитика, геоэкономика, Прикаспийский регион, Черноморско-Каспийский макрорегион, Большой Каспий, мегарегион, пространство, треугольники, пространственное развитие.

Abstract. The Caspian issues are considered in various aspects by numerous domestic and foreign researchers. The region is gaining particular importance in connection with the signing of the Convention on the Legal Status of the Caspian Sea (dated 12.08.2018), which formed new geopolitical and geo-economic realities and a new vector of integration development on the Eurasian continent. More and more attention is paid to the subject of the spatial development of the Great Caspian in the East-West and North-South coordinate systems. The US policy in the Middle East, including sanctions pressure on Iran, is aimed at destabilizing the political and economic situation in the region, and also provides for restraining the progressive development of the largest Asian economies in the world. This paper considers some conceptual approaches to the formation of a concept and a multidimensional model of the Great Caspian Sea, as a geopolitical center of regional and global interests, dynamically changing the spatial conjugation of multi-vector forces of international influence based on institutional transformations. An approach to creating a new geopolitical space within the framework of the "Great Eurasian Triangle RIC" with the base of the "Great Caspian" triangle pulling together the leading players in world politics and encircling the Eurasian continent with the most important transport routes is considered. The formation of "multidimensional spaces" - triangles, as the most stable political-economic and physical-geographical international structures (formations), represent the spatial realities of the Great Caspian Sea, as a new geopolitical dimension - a megaregion.

Key words: geopolitics, geoeconomics, the Caspian region, the Black Sea-Caspian macro-region, the Great Caspian, mega-region, space, triangles, spatial development.

Introduction. The Caspian region is of particular importance in modern geopolitics. More and more attention is paid to the subject of the spatial development of the Great Caspian in the East-West and North-South coordinate systems. Despite the lack of a clear interpretation of the concept of "Caspian region", which is considered by various scientific theories and interpreted in both narrow and broad senses, there is an attempt to integrate it into the Black SeaCaspian region; Mediterranean-Caspian, Caucasian-Caspian and other regions.

Initially, according to American studies, the energy and geopolitical prospects of the Caspian region lay in the fact that it is a continuation of the oil fields of Iran and the entire Middle East. As a result, the Caspian basin and the Persian Gulf began to be considered as a single structure, and the Caspian basin was inscribed by the West in its geopolitical megaprojects [17, p.39-40].

The Convention on the Legal Status of the Caspian Sea initiated an increase in the processes of regional and transboundary cooperation, incl. on the formation of a transport and communication framework and a common economic space of the Caspian states. With a new stage in the development of integration processes and the implementation of energy megaprojects, the geopolitical status of the region is changing. 
In the scientific literature, the concept of the "Great Caspian" is introduced, which is characterized by the physical and geographical features of the region and does not fully fit into the ideology of Eurasianism, leaving significant theoretical gaps in these studies.

So, in the terminology of the European Council, GKR ("The Greater Caspian Region") means a territory that includes, in addition to five coastal countries (Russia, Azerbaijan, Kazakhstan, Turkmenistan, Iran), also closely located countries, historically, economically and culturally related to the Caspian Sea, these are Armenia, Georgia and Uzbekistan [28, p.30].

In the work of the former American diplomat R.E. Hoagland "Greater Caspian Region: Competition and Cooperation" (2019) The Caspian is represented by "a center of growing strategic importance", "quiet background buzz", "one of the largest hydrocarbon deposit centers in the world", having "growing interest and strategic importance throughout the world ", For whose influence" four global powers are fighting: Russia, China, the United States and Europe - all for different reasons and with sometimes conflicting interests. " As a result of growing competition, the Greater Caspian region really has a growing interest and strategic importance all over the world [36, p.10-11].

In the geo-economic dictionary-reference book, the "Greater Caspian" is defined as a geopolitical region that emerged in Eurasia as a result of the collapse of the Soviet Union. The Caspian region includes five countries directly facing the sea-lake (Russia, Kazakhstan, Turkmenistan, Iran and Azerbaijan). In an extended interpretation, it includes the South Caucasus and Central Asia [6, p.15].

Professor A.K. Magomedov also used "an extended interpretation of the term, referring to it as the" Greater Caspian, "including the Russian North Caucasus, Transcaucasia and Central Asia - key areas of geopolitical and energy struggles in modern Northern Eurasia. These areas are united in the "Greater Caspian" by the logic and the struggle to form oil and gas pipelines and transport corridors "[16, p.11].

A broader interpretation was suggested by Professor P.L. Karabuschenko, according to which the geopolitical space of the Caspian cannot be limited to five states that have direct access to the sea. The Caspian Five (Russia, Kazakhstan, Turkmenistan, Iran and Azerbaijan) is supplemented by the Caspian Ten (Ukraine, Turkey, Georgia, Armenia, Iraq, Kyrgyzstan, Uzbekistan, Tajikistan, Afghanistan, Pakistan) and the world three of interested states are added (USA, EU, China) [14, p.17]. In his opinion, such an expanded interpretation of this geopolitical space makes it possible to comprehensively take into account all the changes that occur here or that have an impact on it from outside. Therefore, in the structure of the Caspian geopolitics, he singles out such components as the "Caspian axis" - (Caspian five) and "Caspian arc" - (Caspian ten). In the presence of all these components, we can talk about the existence of a "Great geopolitical Caspian region", great in the literal and figurative sense of the word, because it will really be the center or the core of the entire Eurasian continent [14, p.17].

P.L. Karabuschenko in his understanding of the "Great geopolitical Caspian region" was based on the logic of the reasoning of the English geopolitical scientist Kh.D. Mackinder on the "heart of the world" or "Heartland" and the "Pivot Area". In his opinion, the Central Asian space is indeed acquiring the meaning of the "Heartland" of classical German geopolitics. Here the lines of force of civilizational and confessional, ethnic and political faults, aggravated by a tough struggle for natural resources and living space, converge [21, p.331].

The variety of views and assessments allows us to state that the definition of the Greater Caspian contains some historical geopolitical characteristics, and in terms of content - a set of geopolitical projects of "energy and economic influence" and, first of all, against the growing role of China and Russia in the formation of a new world order.

Spatial development as a factor of communication connectivity of territories (international spaces).

With the changes in the geopolitical situation in the world, there have been corresponding alteration in the Caspian region, which has become a global geopolitical object, around which the diplomatic struggle of the leading world powers for the possession of natural resources and control of transport routes has developed [20, p.89].

The peculiarity of the directions of development of spatio-temporal concepts consists in giving them the processes of "social evolution" [23, p.13]. Comprehensive analysis and programming of human life, considered from the point of view of the territorial organization of society, acquires special relevance at the present time, when "contradictory processes of globalization and regionalization, spatial integration and differentiation, democratization and monopolization have been activated" $[31, \mathrm{p} .4]$.

The structure of the territorial social system, which forms a multidimensional space, determines [31, p.7]:

- human life environment, including a set of subsystems: economic, natural, social, spiritual, recreational;

- infrastructural components of subsystems: production, market, environmental, social, spiritual, recreational, military, institutional, etc.

According to numerous studies, the concept of economic space is divided into two extreme views, both real (physical) space and abstract (conceptual). At the same time, some scholars believe that economic space is both a concentration of socio-economic infrastructure and economic relations, that is, they allow the existence of both real and conceptual spaces [3].

Obviously, in the context of the task set by the authors - the formation of the concept of the "Greater Caspian", this topic needs more in-depth research, taking into account modern geopolitical and geo-economic processes at the macroeconomic level.

Black Sea-Caspian macro-region in the system of spatial geopolitical development. 
In scientific literature, the concept of "macroregion", in contrast to the mega-region, is purely economic in nature, since it does not include a historical, social and cultural community [30, p. 131]. According to V.I. Suprun, the macro-region belongs to the sphere of economics and fixes the correlation of economic relations, both in resource and production relations, therefore Europe, and in its person the European Economic Union, can be considered a developed macro-region [29, p. 171].

At the same time, the Black Sea-Caspian region is considered a special segment of the world geopolitical space, which found itself at the crossroads of the most important transit communications [27]. Within the framework of modern Russian foreign policy and the formation of an international transport framework, the region also plays an important geo-economic significance in the strategy of the country's spatial development and the common economic space of Europe.

The specified macro-region, also defined as the Caucasus-Caspian region, according to the estimates of many researchers $[10 ; 15 ; 33]$ represents: 1$)$ from a geographical point of view - a bridgehead, pulling together the Black Sea and Caspian sea spaces; 2) from the military-strategic point of view - the most important springboard for pressure and offensive in any direction, on any country, not only in this region, but also in adjacent regions; 3 ) a springboard for control over communications; 4) from an economic point of view, it is not only a world crossroads of transport routes along the East-West, North-South axes, but also a region with huge hydrocarbon resources.

At the same time, the potential of the Black Sea-Caspian space is assessed "by the expected large-scale development of Caspian energy resources and the development of transit communications" [24], although in the European vision the region is presented as "a kind of peripheral zone that has its own specifics and generates problems of an economic and migration nature" [24].

In the Black Sea-Caspian space, Iran is the main supplier of hydrocarbons [35], which is of great interest to the world's leading economies (China and India) as a transit corridor. However, the main routes of the Silk Road Economic Belt (SREB) pass through the vast territories of Central Asia, Russia and Europe; Western Asia to the Persian Gulf and the Mediterranean Sea. It is also supposed to create "a new continental bridge between Europe and Asia, international corridors of economic cooperation" China-Mongolia-Russia "and" China - Central Asia - West Asia "" [5, p.87].

The most important document of the European Union, which outlined its desire to strengthen influence in the Black Sea region - the resolution of the European Parliament of January 20, 2011 "EU Strategy for the Black Sea", which notes that "the Black Sea region is a strategic bridge connecting Europe with the Caspian Sea basin, Central Asia and the Middle East, and further, with Southeast Asia and China, and is characterized by its close ties and enormous potential, but also diversity and rivalry "[22, p. 81].

This statement testifies that the Black Sea basin and its infrastructure are considered by the EU and NATO alliance countries as an important element in the transit chain of the strategic (global) transport route in the Eurasian space. Given the limited availability of these routes through the territory of the Russian Federation, bypass options for spatial development along southern streams are being considered: through Georgia, Azerbaijan, Kazakhstan, etc.

The well-known concept of the "Greater Black Sea Region" by R. Asmus has actually transformed into the political direction of the Euro-Atlantic Black Sea region. Its significance is determined by a number of important factors: as "the pivot between the main part of Europe and the" Greater Middle East ""; the attachment of the Black Sea region to the West; the possibility of achieving energy security through diversification of their supplies and new transport routes [2]. At the same time, there remains "an open question about the institutional expression of such a" feedback" ", as well as "doubts about the" Europeanness "of the Black Sea states" [2].

In development of Western initiatives, the Istanbul Declaration was signed on June 26, 1992, which proclaimed the creation of the Black Sea Economic Cooperation Organization (BSEC). However, according to A.R. Nikiforova, over the twenty-year period of its operation, "not a single large-scale project has been implemented and practically did not advance along the path of economic integration of the Black Sea region", therefore "the time has come to understand the Black Sea region as a political region" [22, p.79].

A number of experts are rather skeptical about the socio-political integrity of the region, the presence and prospects of the Black Sea identity. According to P. Dimitrov's estimates, there is no Black Sea political and cultural identification. "People living on and around the Black Sea coast identify themselves as residents of the Balkans, Caucasians, Turks, and even as former Soviet people, but never as people of the Black Sea zone" [34]. Therefore, the region "is not a direction for any separate geopolitics," it is viewed as a space where the interests of the EU, Russia and the United States clash, but "not in the form of geopolitics," but "in the form of infrastructure policy" [7, p. 8].

These features of the formation of the Black Sea region and the identity of its population on the principles of "natural-material" parameters and physical space, are fundamentally different from the ideology of Eurasianism, which is inherent, including the peoples of the Caspian region.

The space of the Greater Caspian Sea as a new geopolitical mega-region.

According to the conceptual ideas of the mega-region, which, in addition to economic (production and resource), is distinguished by "socioeconomic" characteristics, the South Asian zone can be said as a macro-region, agglomerations, and various kinds of unions [30, p.129-130 ]. Therefore, "the economic space of the mega-region is located between the world and national economies [12, p.207].

E.I. Inshakova suggests considering mega-regions as institutional and organizational "forms of transformation of the global economic system (GES)", since they form a group of contiguous countries of the world economy, linked 
by the joint performance of global functions [11, p.12]. However, this definition gives a very abstract description of the concept, since the subject of these functions has not been formulated, and an attempt to unite countries into international regional unions can hardly serve as such a criterion, especially if it "is formed and developed under the influence of ... national character" [11, p. .12].

Analytical studies of the concept of "mega-region" made it possible to group the totality of their characteristic features $[4 ; 9 ; 13 ; 29]$ :

- the development potential of the "mega-region" system is formed by a wide range of factors designed to ensure sustainable development of the regional economy;

- mega-regions are "locomotives" of sustainable economic development of their countries on the basis of integration-balanced interaction;

- the institutional factors of a mega-region's development are determined by its institutional environment, which, in accordance with the theory of institutionalism, is a set of fundamental political, social and legal rules that form the basis for production, exchange and distribution;

- the institutional environment of the mega-region - the rules of behavior determined from the outside (by the external environment, or exogenously set) in political, social and legal aspects, and the relations underlying the organization - the mega-region, that is, set endogenously;

- assumes the presence of large centers of attraction. Within the mega-region, rich regions appear, elites who do not want to share not economically, not power, "they do not want to share culturally either";

- does not imply the obligatory existence of an administrative capital;

- changes the ideology of international cooperation: from the paradigm of liberal globalization in the interests of private capital of the leading countries of the world is being replaced by the paradigm of sustainable development in the interests of all mankind;

- forms the concept of socially conservative synthesis as an ideological basis for reforming international monetary, financial and economic relations based on the principles of justice, mutual respect for national sovereignty and mutually beneficial exchange.

According to N.V. Gorbacheva energy sector is an important factor in ensuring the sustainability and development of mega-regions [29, pp. 173-174]:

- energy security, ensuring the sufficiency of energy resources for sustainable development;

- energy independence, determined by import-export dependence and the reliability of these flows;

- environmental challenges accompanied by climate change and an increasing impact on the environment.

In these conditions, the most important factors in the development of the mega-region are distinguished, accompanied by global effects - an increase in the quality of life of the population on the basis of its sustainable reproduction development and the formation of an attractive institutional environment [9, p.97]:

- development of innovative potential and increasing investment activity;

- increasing investment attractiveness;

- integration-balanced interaction of the mega-region vertically (with systems of a higher level) and horizontally (with equal-level systems and with elements of the system itself);

- increasing the competitiveness and competitive stability of the mega-region.

In the new geopolitical realities, the Caspian region is viewed as: part of the vast territory of the "Eurasian Balkans"; part of a vast territory - Eurasia; a connecting link between the Central Asian and Black Sea areas or a connecting link in the North - South direction (Russia - Persian Gulf). In this context, the point of view of S.A. Proskurin and K.G. Landa, considering the Caspian region as a logical continuation of the Indo-Persian, Caucasian-Black Sea, Central Asian and Volga-Ural geopolitical regions [26, p.192].

In our opinion, the concept of "Caspian region", which is actively used in periodicals and scientific literature, is based more on intuitive understanding than on a clear definition based on certain characteristics, is still interpreted ambiguously and sometimes contradictory. Recently, as an ideological justification for the integration of the CIS countries, they started talking about a new understanding of Eurasianism. The Caspian region is the center of Eurasia, so it is here that these ideas have always met the most direct interest [19, p.15].

Considering the region in a narrow sense, as a territory adjacent to the sea, it can be represented schematically as a model of the small Caspian region (Fig. 1).

The proposed model, in contrast to those traditionally described in the literature, shows the presence of developing partnerships between all countries in the region. The multi-vector nature of further development of cooperation within the framework of the model of the small Caspian region (similar to the accepted interpretation of the region in the narrow sense) is ensured through the participation of five Caspian states in the activities of various international organizations.

The diversity of the interweaving of these relationships both between the Caspian countries and their indirect political, trade and economic participation with third states through bilateral or multilateral relations through international organizations, form a new configuration of the spatial development of the Eurasian continent.

\begin{tabular}{|c|c|c|}
\hline \multicolumn{3}{|c|}{ Shanghai Cooperation Organization (SCO) } \\
\hline$\Xi \frac{0}{0}$ & Caspian region & 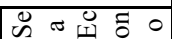 \\
\hline
\end{tabular}




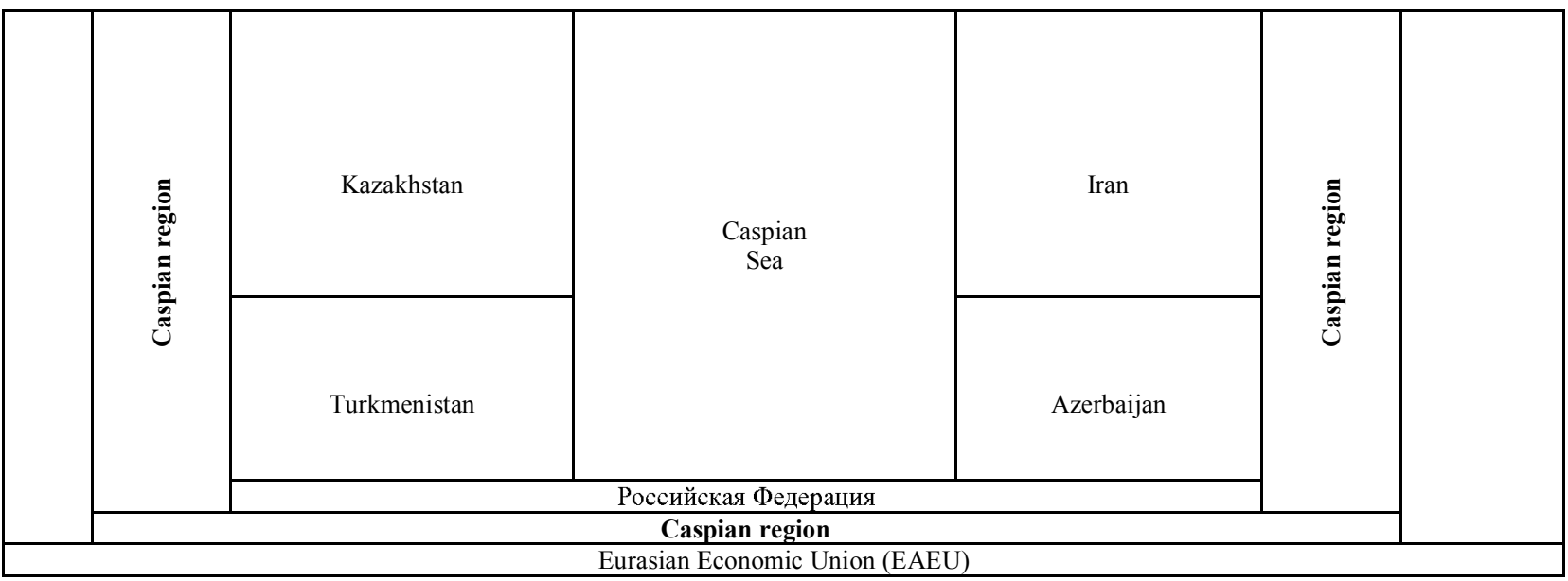

Source: author

Fig. 1. Model of the space of the small Caspian region

For example, Iran is an important state through which the implementation of the Eurasian integration policy of Russia and China is ensured; Russia and India. The resource potential of hydrocarbons passing through the Strait of Hormuz reaches $40 \%$ of world trade and $20 \%$ of oil trade, its geographical position connects the Caucasus and Central Asia with the Arabian Peninsula, India with Sweden, Afghanistan with Turkey, etc. [25].

Coupling Eurasian integration based on the construction of the Eurasian Economic Union and the Silk Road Economic Belt provides the formation of a transit space between China and Europe according to various options (along the Trans-Siberian Railway along its entire length; transportation of Chinese goods to Russia through Kazakhstan; transit from China to Europe bypassing Russia - through Kazakhstan and Iran) [18, p.46-47].

Simultaneously with the formation of the vast space of Greater Eurasia (from the ASEAN countries and Korea in the east, India in the south to the Transcaucasus in the west), new geopolitical and geoeconomic systems of "interconnections - transport, trade and investment, human, political", as well as free trade zones, unity of norms and standards are being created. At the same time, the economic potential of "China and India provide a safety cushion for the new co-development space" [17, p. 54].

Given the special modern geopolitical and geo-economic strategic importance, the Caspian region has become the epicenter of international processes. The uniformity of most points of view lies in its recognition as a transboundary macro-region, in the formation of which "more than 30 regional, extra-regional and global political, economic, military actors, represented by states, organizations and companies, are involved" [1, p.53]. The transboundary status of a region is an institutional form of organizing transboundary cooperation [32], which can be characterized as a "natural economic zone" [37] of regional development.

In terms of the combination of these factors and conditions, the Caspian region as a "subject" appears to be a more complex configuration of geopolitical relations that requires clarification of the modern concept. Initially, it was not so united and did not have a common legal framework and a specific legal status. Therefore, there were several levels of "maturation" of the subject's essence of geopolitical characteristics: (a) the unity and integrity of the cultural, historical and geographical space; (b) cooperation of political and economic activities of all entities; (c) common strate gic interests and priorities; (d) formation or presence of a "territorial (regional) idea"; (e) a unified legal field [8, p.35-36].

The participation of the Caspian states in the activities of various international organizations, as well as the development of bilateral and multilateral political, trade and economic relations, allow us to form a developing vector of the spatial model of the "small Caspian region". The matrix and status of states in the main international organizations that form the Greater Caspian Sea space (Table 1) indicates the possibility of creating a multi-vector and multidirectional space for further development of international cooperation within the Greater Caspian Sea.

Table 1

Matrix and status of states in the main international organizations, forming the space of the Greater Caspian

\begin{tabular}{|c|c|c|c|c|c|c|c|c|c|c|c|c|}
\hline \multirow{3}{*}{$\begin{array}{l}\text { Countries of } \\
\text { Caspian } \\
\text { region }\end{array}$} & \multicolumn{2}{|c|}{$\begin{array}{l}\text { Commonwealth } \\
\text { Independent } \\
\text { States (CIS) }\end{array}$} & \multicolumn{3}{|c|}{$\begin{array}{l}\text { Shanghai Cooperation } \\
\text { Organization (SCO) }\end{array}$} & \multicolumn{3}{|c|}{$\begin{array}{l}\text { Organization of the } \\
\text { Black Sea } \\
\text { Economic cooperation } \\
\text { (BSEC) }\end{array}$} & \multicolumn{4}{|c|}{$\begin{array}{l}\text { Eurasian Economic Union } \\
\text { (EAEU) }\end{array}$} \\
\hline & \multirow{2}{*}{$\begin{array}{l}\text { Full } \\
\text { members }\end{array}$} & \multirow{2}{*}{$\begin{array}{l}\text { Associate } \\
\text { members }\end{array}$} & \multirow{2}{*}{ Participants } & \multirow{2}{*}{$\mid \begin{array}{c}\text { Observers / } \\
\text { Observer } \\
\text { Application }\end{array}$} & \multirow{2}{*}{$\begin{array}{l}\text { Dialogue } \\
\text { partners }\end{array}$} & \multirow{2}{*}{ Participants } & \multirow{2}{*}{ Observers } & \multirow{2}{*}{ partners } & \multirow{2}{*}{ Members } & \multirow{2}{*}{ Observers } & \multicolumn{2}{|c|}{$\begin{array}{l}\text { Free zone } \\
\text { trade }\end{array}$} \\
\hline & & & & & & & & & & & agreement & $\begin{array}{c}\text { Conversation/ } \\
\text { interest }\end{array}$ \\
\hline \multicolumn{13}{|c|}{ The status of the states parties to the Convention on the Legal Status of the Caspian Sea dated 12.08.2018 } \\
\hline Azerbaijan & $\mathrm{X}$ & & & & $\mathrm{X}$ & $\mathrm{X}$ & & & & & & \\
\hline Iran & & & & $\mathrm{X}^{\prime}$ & & & & $\mathrm{X}$ & & & $\mathrm{X}$ & \\
\hline Kazakhstan & $\mathrm{X}$ & & $\mathrm{X}$ & & & & & & $\mathrm{X}$ & & & \\
\hline Russia & $\mathrm{X}$ & & $\bar{X}$ & & & $\bar{X}$ & & & $\mathrm{X}$ & & & \\
\hline
\end{tabular}




\begin{tabular}{|c|c|c|c|c|c|c|c|c|c|c|c|c|}
\hline Turkmenistan & & $\mathrm{X}$ & & & & & & & & & & \\
\hline \multicolumn{13}{|c|}{ States - strategic partners of the countries of the Caspian region, the EAEU and the SCO } \\
\hline Armenia & $\mathrm{X}$ & & & & $\mathrm{X}$ & $\mathrm{X}$ & & & $\mathrm{X}$ & & & \\
\hline Belarus & $\mathrm{X}$ & & & $\mathrm{X}^{\prime}$ & & & $\mathrm{X}$ & & $\mathrm{X}$ & & & \\
\hline India & & & $\mathrm{X}$ & & & & & & & & & negotiation \\
\hline China & & & $\mathrm{X}$ & & & & & & & & $\mathrm{X}$ & \\
\hline Kyrgyzstan & $\mathrm{X}$ & & $\mathrm{X}$ & & & & & & $\mathrm{X}$ & & & \\
\hline Pakistan & & & $\mathrm{X}$ & & & & & & & & & \\
\hline Moldova & $\mathrm{X}$ & & & & & $\mathrm{X}$ & & & & $\mathrm{X}$ & & \\
\hline Serbia & & & & & & $\mathrm{X}$ & & & & & $\mathrm{X}$ & \\
\hline Tajikistan & $\mathrm{X}$ & & $\mathrm{X}$ & & & & & & & & & \\
\hline Turkey & & & & & $\mathrm{X}$ & $\mathrm{X}$ & & & & & & \\
\hline Uzbekistan & $\mathrm{X}$ & & $\mathrm{X}$ & & & & & & & & & \\
\hline \multicolumn{13}{|c|}{ States that are among the leading and developing economies of the world } \\
\hline Egypt & & & & $/ \mathrm{X}$ & & & $\mathrm{X}$ & & & & & negotiation \\
\hline Vietnam & & & & A & & & & & & & $\mathrm{X}$ & \\
\hline Korea & & & & & & & & $X$ & & & & interest \\
\hline Singapore & & & & & & & & & & & $\mathrm{X}$ & \\
\hline Japan & & & & & & & & $\mathrm{X}$ & & & & \\
\hline
\end{tabular}

Source: author

The proposed matrix and status of states in the main international organizations that form the space of the Greater Caspian Sea (see Table 1) is characterized by a combination of the diversity of geopolitical subjects. The linear model of their construction and institutional transformations determines the status of states that are part of interconnected international organizations, which are distributed at the appropriate levels:

1) First - regional level:

1.1. The countries of the Caspian region, forming the space of the small Caspian region (see Fig. 1);

1.2. The legal status of the countries of the Caspian region in the main international organizations operating in the Eurasian space (full or associate member; participant, observer or dialogue partner; participant, observer or partner; members, observers, participants in the free trade zone).

2) The second is the macro level:

2.1. The main international organizations in which the Russian Federation participates in the Eurasian space (CIS, SCO, BSEC, EAEU);

2.2. The legal status of states in a particular international organization (full or associate member; participant, observer or dialogue partner; participant, observer or partner; members, observers, participants in the free trade zone).

3) The third - mega-level:

3.1. States parties to the Convention on the Legal Status of the Caspian Sea;

3.2. States are strategic partners of the countries of the Caspian region, the EAEU and the SCO;

3.3. States that are among the leading and developing economies of the world.

As a result of institutional transformations, the physical and geographical space of the Greater Caspian Sea can be gradually formed, which is represented by a large number of various states of almost all continents of the Earth, differing in the level of development: productive forces and production relations; political systems and political structure, foreign and domestic policy, as well as other historical, socio-economic and cultural characteristics. At the same time, a basis for building a multidimensional model of the Greater Caspian Sea is being created, a dynamically changing spatial conjugation of various forces of international influence. Within the framework of this space, a set of two and - trilateral ties and relations is formed as the most stable geopolitical and "spatial units".

Thus, the Syrian events (from September 30, 2015 to the present) contributed to the creation of the most effective military-political coalition of states (Russia - Iran - Turkey), which is actually transforming into the southwestern vector of the "Greater Caspian Triangle" - a zone of collective security in the south Caspian space. The strategic triangle also covers the most "explosive regions" of the world: the Caspian and Black Sea basins - the Mediterranean - the Persian Gulf - the Arabian Sea.

The Caspian southeastern Eurasian vector (Eurasian turn), which forms a new geopolitical space of the Greater Caspian Sea, is carried out within the framework of the "Greater Eurasian Triangle RIC" (Russia - India - China), as an established format of political interaction between states. The importance of this cooperation is determined by the traditionally developing trade and economic relations, as well as the possibilities of conjugating Eurasian integration in the implementation of global projects: the Chinese Economic Belt of the Silk Road and the International North-South Transport Corridor, which expands India's accessibility to international transport communications and hydrocarbon resources.

Conclusions. The new geopolitical space, formed within the framework of the "Greater Eurasian Triangle RIC" with the base of the "Greater Caspian" triangle, which pulls together the leading players in world politics, encircling the Eurasian continent with the most important transport routes, is characterized by specific economic, geopolitical and physical and geographical features of this mega-region. 
The changing geopolitical alignment in the world based on the formation of "multidimensional spaces" - triangles, as the most stable political and economic international structures (formations), represent new spatial realities of the geopolitical dimension of the multipolar world order in the system of world coordinates and their increasing influence in the Eurasian space, "axial zone "which is occupied by the Greater Caspian.

\section{ЛИТЕРА ТУРА}

1. Алиев Ш.М., Магомедова А.И. Кавказско-Каспийский регион: новая евразийская реальность //Известия ДГПУ, 2017. T. 11. № 2. C.50-57.

2. Асмус Р. Евро-атлантическое Причерноморье // Россия в глобальной политике, Май - Июнь 2007. № 3. URL: https://globalaffairs.ru/number/n_8817

3. Астапенко М.С. Теории и концепции пространственной экономики: суцностные аспекты и эволюция подходов // Вестник Евразийской науки, 2018. №1. URL: https://esj.today/PDF/50ECVN118.pdf

4. Глазьев С.Ю. Мирохозяйственные уклады в глобальном экономическом развитии // Экономика и математические методы, 2016. Т. 52. № 2. С. 3-29.

5. Гончаренко С.І. Черноморское экономическое сотрудничество: первые 25 лет - Black Sea Economic Cooperation: the First 25 Years. М.: Ин-т Европы PAI, 2018. $114 \mathrm{c.}$

6. Дергачев В.А. Геоэкономический словарь-справочник. Одесса: ИТРЭЭИ НАНУ, 2004. 177с

7. Дацюк С. Зіткнення інтересів CC, Росії та CША в Чорному морі в інфраструктурній політиці. URL: http://dialogs.org.ua/dialog.php?id=58\&op_id=992\#992.

8. Дмитриев А.В, Карабущенко П.Л., Усманов Р.Х. Геополитика Каспийского региона (Взгляд из России). Астрахань: Изд-во АГУ, 2004. $318 \mathrm{c}$.

9. Дробкова О. С. Факторы и потенциал устойчивого развития мегарегиона // Вестник КемГУ. Серия: Политические, социологические и экономические науки, 2018. № 3. С. 94-100.

10. Зонн И.С., Жильцов С.С. Новый Каспий. География, экономика, политика. М.: Восток-Запад, 2008. 544 с.

11. Иншакова Е.И. Экономическая интеграция в СІГ: методология, стратегия, механизм. Волгоград: Волгогр. науч. изд-во, 2005. 372 с.

12. Иншаков О. В., Иншакова Е. И. Мегарегионы: проблемы измерения динамики и структуры процессов глобализации // Экономика развития региона: проблемы, поиски, перспективы, 2008. № 9. С. 206 -217.

13. Иншакова Е.И. Формирование мегарегионов в мировой и национальной экономике. URL: http://refleader.ru/jgeotrujgjgepol.html

14. Карабущенко П.Л. Элиты и этноконфликты в геополитическом пространстве «великого Каспийского региона» // «Каспийский регион: Политика, экономика, культура», 2009. № 3. С. 17-22.

15. Котилко В.В. Сценарии создания организации каспийского экономического сотрудничества // Национальные интересы: приоритеты и безопасность. 2011. № 11 (104). С. 19-33.

16. Магомедов А.К. Каспий - Кавказ - Причерноморье: пути нефти, пути торговли, пути войны (история и современность). Ульяновск: УлГТУ, 2018. $250 \mathrm{c}$.

17. Магомедов А.К. Югоосетинский конфликт и рубежи борьбы за энергоресурсы Большого Каспия // Центральная Азия и Кавказ. 2009. Т. 62. № 2. С. 36-50.

18. Макаров И.А., Соколова А.К. Сопряжение евразийской интеграции и Экономического пояса Шелкового пути: возможности для России // Вестник международных организаций, 2016. Т. 11. №2. С. 40-57.

19. Маркелов К.А. Актуальные проблемы политико-экономической безопасности стран Каспийского региона в начале XXI века: монография. М.: Ин-т междунар. социально-гуманитарных связей, 2011. 167 с.

20. Маркелов К.А. Социально-политические вызовы и угрозы в Каспийском геополитическом пространстве начала XXI в. // МИР (Модернизация. Инновации. Развитие), 2011. № 7. С. 88-93.

21. Новейшая политическая история: Прикаспийская «геополитическая ось» (1991-2011 гг.): учебное пособие / под ред. П.Л. Карабущенко. М.: ИНФРА-М, 2019. 358 с.

22. Никифоров А.Р. Черноморский регион: пространство и время //Ученые записки Крымского федерального университета имени В. И. Вернадского. Сер. Философия. Политология. Культурология. 2016. Т.2 (68). № 4. С. $78-87$.

23. Носонов А.М. Теории пространственного развития в социально-экономической географии // Псковский регионологический журнал, 2011. № 11. С. 3-16.

24. Парахонский Б. Черноморско-Каспийский регион в европейском контексте: новые ориентиры безопасности и сотрудничества. URL:https://ca-c.org/journal/2003/journal_rus/cac-02/20.parrus.shtml

25. Попова В. Геополитические причины ирано-американского кризиса и Большая Евразия, 08.01.2020. URL:https://www.ritmeurasia.org/news--2020-01-08--geopoliticheskie-prichiny-irano-amerikanskogo-krizisa-i-bolshaja-evrazija46848

26. Проскурин С.А., Ланда К.Г. Каспийский регион и геополитика России // Геополитические вызовы и внешнеполитическая деятельность России, 2002. №5. С. 192.

27. Розин М.Д., Рябцев В.І., Свечкарев В.П. Черноморско-Каспийский регион как поле «Большой игры»: классификационный системный анализ / Электронный научный журнал «Инженерный вестник Дона». URL: http://www.ivdon.ru/ru/magazine/archive/n3y2016/3741

28. Сергунин А.А., Тихонов В.Г. «Восточное партнерство» и «Больпой Каспийский регион»: проблемы и перспективы // Каспийский регион: политика, экономика, культура, 2009. №3(20). С.30-38.

29. Сибирь как мегарегион. Круглый стол //Идеи и Идеалы, 2016. № 1(27). С. 167-181.

30. Супрун В.И. Сибирь как мегарегион: концепция и реальность //Идеи и Идеалы, 2016. № 1(27). Т.1. С. $124-134$.

31. Шарыгин М.Д., Столбов В.А. Тенденции становления отечественной общественной географии: теоретикометодологические аспекты // Географический вестник, 2006. №2. С. 4-10. 
32. Яровой Г., Белокурова Е. Европейский союз для регионов: что можно и нужно знать российским регионам о ЕС. СПб.: Норма, 2012. $368 \mathrm{c.}$

33. Aliyev Kenan. Security in the Caucasus: Caspian Crossroads Interview with US Lt. Gen. William E. Odom. Caspian Crossroads Magazine Volume 4, Issue\#2, Winter 1999.

34. Dimitrov P. Wider Black Sea and the New Frontiers of European Geopolitical Space. URL:

http://www.aiprg.net/UserFiles/File/black_sea_conf_papers/Plamen_Dimitrov_paper.pdf.

35. Europe's Black Sea Dimension. Terry D. Adams, Michael Emerson, Laurence David Mee and Marius Vahl. Centre for European Policy Studies. Athens-Brussels. 2002. P. 6-8.

36. Hoagland R.E. The greater Caspian region: competition and cooperation // Caspian Magazine affairs, January-February

2019. C.10-22.URL: https://www.caspianpolicy.org/wp-content/uploads/2019/10/Caspian-Affairs-Magazine-January-Issue-2019-

1.pdf

37. Ohmae, K. The Rise of the Region State// International Affairs. 1993. Vol. 72. № 2. P. 78-87.

\section{REFERENCES}

1. Aliev SH.M., Magomedova A.I. Kavkazsko-Kaspijskij region: novaya evrazijskaya real'nost' //Izvestiya DGPU, 2017. T. 11. № 2. S.50-57.

2. Asmus R. Evro-atlanticheskoe Prichernomor'e // Rossiya v global'noj politike, Maj - Iyun' 2007. № 3. URL: https://globalaffairs.ru/number/n_8817

3. Astapenko M.S. Teorii i koncepcii prostranstvennoj ekonomiki: sushchnostnye aspekty i evolyuciya podhodov // Vestnik Evrazijskoj nauki, 2018. №1. URL: https://esj.today/PDF/50ECVN118.pdf

4. Glaz'ev S.YU. Mirohozyajstvennye uklady v global'nom ekonomicheskom razvitii // Ekonomika i matematicheskie metody, 2016. T. 52. № 2. S. 3-29.

5. Goncharenko S.N. Chernomorskoe ekonomicheskoe sotrudnichestvo: pervye 25 let - Black Sea Economic Cooperation: the First 25 Years. M.: In-t Evropy RAN, 2018. $114 \mathrm{~s}$.

6. Dergachev V.A. Geoekonomicheskij slovar'-spravochnik. Odessa: IPREEI NANU, 2004. 177s.

7. Dacyuk S. Zitknennya interesiv CS, Rosiï ta SSIIA v CHlornomu mori v infrastrukturnij politici. URL: http://dialogs.org.ua/dialog.php?id=58\&op_id=992\#992.

8. Dmitriev A.V, Karabushchenko P.L., Usmanov R.H. Geopolitika Kaspijskogo regiona (Vzglyad iz Rossii). Astrahan': Izd-vo AGU, 2004. $318 \mathrm{~s}$.

9. Drobkova O. S. Faktory i potencial ustojchivogo razvitiya megaregiona // Vestnik KemGU. Seriya: Politicheskie, sociologicheskie i ekonomicheskie nauki, 2018. № 3. S. 94-100.

10. Zonn I.S., Zhil'cov S.S. Novyj Kaspij. Geografiya, ekonomika, politika. M.: Vostok-Zapad, 2008. 544 s.

11. Inshakova E.I. Ekonomicheskaya integraciya v SNG: metodologiya, strategiya, mekhanizm. Volgograd: Volgogr. nauch. izd-vo, 2005. $372 \mathrm{~s}$.

12. Inshakov O. V., Inshakova E. I. Megaregiony: problemy izmereniya dinamiki i struktury processov globalizacii // Ekonomika razvitiya regiona: problemy, poiski, perspektivy, 2008. № 9. S. $206-217$.

13. Inshakova E.I. Formirovanie megaregionov $\mathrm{v}$ mirovoj $\mathrm{i}$ nacional'noj ekonomike. URL: http://refleader.ru/jgeotrujgjgepol.html

14. Karabushchenko P.L. Elity i etnokonflikty v geopoliticheskom prostranstve «velikogo Kaspijskogo regiona» // «Kaspijskij region: Politika, ekonomika, kul'tura», 2009. № 3. S. 17-22.

15. Kotilko V.V. Scenarii sozdaniya organizacii kaspijskogo ekonomicheskogo sotrudnichestva // Nacional'nye interesy: prioritety i bezopasnost'. 2011. № 11 (104). S. 19-33.

16. Magomedov A.K. Kaspij - Kavkaz - Prichernomor'e: puti nefti, puti torgovli, puti vojny (istoriya i sovremennost'). Ul'yanovsk: UlGTU, 2018. $250 \mathrm{~s}$.

17. Magomedov A.K. YUgoosetinskij konflikt i rubezhi bor'by za energoresursy Bol'shogo Kaspiya // Central'naya Aziya i Kavkaz. 2009. T. 62. № 2. S. 36-50.

18. Makarov I.A., Sokolova A.K. Sopryazhenie evrazijskoj integracii i Ekonomicheskogo poyasa SHelkovogo puti: vozmozhnosti dlya Rossii // Vestnik mezhdunarodnyh organizacij, 2016. T. 11. № 2. S. 40-57.

19. Markelov K.A. Aktual'nye problemy politiko-ekonomicheskoj bezopasnosti stran Kaspijskogo regiona v nachale XXI veka: monografiya. M.: In-t mezhdunar. social'no-gumanitarnyh svyazej, 2011. 167 s.

20. Markelov K.A. Social'no-politicheskie vyzovy i ugrozy v Kaspijskom geopoliticheskom prostranstve nachala XXI v. // MIR (Modernizaciya. Innovacii. Razvitie), 2011. № 7. S. 88-93.

21. Novejshaya politicheskaya istoriya: Prikaspijskaya «geopoliticheskaya os'» (1991-2011 gg.): uchebnoe posobie / pod red. P.L. Karabushchenko. M.: INFRA-M, 2019. 358 s.

22. Nikiforov A.R. Chernomorskij region: prostranstvo i vremya//Uchenye zapiski Krymskogo federal'nogo universiteta imeni V. I. Vernadskogo. Ser. Filosofiya. Politologiya. Kul'turologiya. 2016. T.2 (68). № 4. S. $78-87$.

23. Nosonov A.M. Teorii prostranstvennogo razvitiya v social'no-ekonomicheskoj geografii // Pskovskij regionologicheskij zhurnal, 2011. № 11. S. 3-16.

24. Parahonskij B. Chernomorsko-Kaspijskij region v evropejskom kontekste: novye orientiry bezopasnosti i sotrudnichestva. URL:https://ca-c.org/journal/2003/journal_rus/cac-02/20.parrus.shtml

25. Popova V. Geopoliticheskie prichiny irano-amerikanskogo krizisa i Bol'shaya Evraziya, 08.01.2020. URL:https://www.ritmeurasia.org/news--2020-01-08--geopoliticheskie-prichiny-irano-amerikanskogo-krizisa-i-bolshaja-evrazija46848

26. Proskurin S.A., Landa K.G. Kaspijskij region i geopolitika Rossii // Geopoliticheskie vyzovy i vneshnepoliticheskaya deyatel'nost' Rossii, 2002. №5. S. 192.

27. Rozin M.D., Ryabcev V.N., Svechkarev V.P.Chernomorsko-Kaspijskij region kak pole «Bol'shoj igry»: klassifikacionnyj sistemnyj analiz / Elektronnyj nauchnyj zhurnal «Inzhenernyj vestnik Dona». URL: http://www.ivdon.ru/ru/magazine/archive/n3y2016/3741 
28. Sergunin A.A., Tihonov V.G. «Vostochnoe partnerstvo» i «Bol'shoj Kaspijskij region»: problemy i perspektivy // Kaspijskij region: politika, ekonomika, kul'tura, 2009. №3(20). S.30-38.

29. Sibir' kak megaregion. Kruglyj stol //Idei i Idealy, 2016. № 1(27). S.167-181.

30. Suprun V.I. Sibir' kak megaregion: koncepciya i real'nost' //Idei i Idealy, 2016. № 1(27). T.1. S. 124- 134.

31. Sharygin M.D., Stolbov V.A. Tendencii stanovleniya otechestvennoj obshchestvennoj geografii: teoretikometodologicheskie aspekty // Geograficheskij vestnik, 2006. №2. S. 4-10.

32. Yarovoj G., Belokurova E. Evropejskij soyuz dlya regionov: chto mozhno i nuzhno znat' rossijskim regionam o ES. $\mathrm{SPb}$.: Norma, 2012. $368 \mathrm{~s}$.

33. Aliyev Kenan. Security in the Caucasus: Caspian Crossroads Interview with US Lt. Gen. William E. Odom. Caspian Crossroads Magazine Volume 4, Issue\#2, Winter 1999.

34. Dimitrov P. Wider Black Sea and the New Frontiers of European Geopolitical Space. URL: http://www.aiprg.net/UserFiles/File/black_sea_conf_papers/Plamen_Dimitrov_paper.pdf.

35. Europe's Black Sea Dimension. Terry D. Adams, Michael Emerson, Laurence David Mee and Marius Vahl. Centre for European Policy Studies. Athens-Brussels. 2002. P. 6-8.

36. Hoagland R.E. The greater Caspian region: competition and cooperation // Caspian Magazine affairs, January-February 2019. S.10-22.URL: https://www.caspianpolicy.org/wp-content/uploads/2019/10/Caspian-Affairs-Magazine-January-Issue-20191.pdf

37. Ohmae, K. The Rise of the Region State // International Affairs. 1993. Vol. 72. № 2. P. $78-87$.

\section{ОБ ABTOPE | ABOUT AUTHOR}

Маркелов Кошстантин А.лексевич, канд. экон. наук, доцент, Астраханский государственшый университет, 414056, Российская Федерация, г. Астрахань, ул. Татищева, 20a, E-mail: asu@asu.edu.ru, ORCID http://orcid.org/0000-0001-8218-4496

Markelov Konstantin Alekseyevich, Ph.D., Associate Professor, Astrakhan State University, 414056, Russian Federation, Astrakhan, Tatishcheva str., 20a, E-mail: asu@asu.edu.ru, ORCID http://orcid.org/0000-0001-8218-4496

Дата поступления в редакцию: 02.02.2020

После рецензирования: 23.04.2020

Дата принятия к публикации: 25.05.2020 